\title{
The Relation Between Serum P-selectin, Thrombin-activatable Fibrinolysis Inhibitor Levels, and Carotid Artery Intima-media Thickness in Acute Ischemic Stroke
}

\author{
Akut İskemik İnmede Serum P-selektin ve Trombin ile Aktive Olabilen Fibrinolizis \\ İnhibitörü Düzeylerinin Karotis Arter İntima Media Kalınlı̆̆ı ile İlişkisi
}

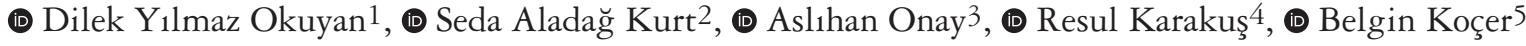 \\ ${ }^{1}$ Konya Numune State Hospital, Clinic of Neurology, Konya, Turkey \\ 2Istanbul University-Cerrahpasa, Cerrahpasa Faculty of Medicine, Department of Radiology, Istanbul, Turkey \\ 3Baskent University Faculty of Medicine, Department of Radiology, Ankara, Turkey \\ ${ }^{4}$ Gazi University Faculty of Medicine, Department of Microbiyology, Ankara, Turkey \\ ${ }^{5}$ Gazi University Faculty of Medicine, Department of Neurology, Ankara, Turkey
}

\begin{abstract}
Objective: Inflammation and migration of leukocytes to the brain parenchyma play a role in atherosclerosis and cerebral ischemic stroke. Migration occurs with the help of adhesion molecules on the surface of cerebral endothelial cells and leukocytes. P-selectin, an adhesion molecule, is present on the platelet and endothelial surface and allows leukocytes to loosely adhere to the endothelium, and its increase has been shown in acute ischemic stroke (AIS). Thrombin-activatable fibrinolysis inhibitor (TAFI) is a procarboxypeptidase molecule that can be another marker of AIS, which has been shown to increase the risk of thromboembolism and stroke 6-fold. Intima-media thickness (IMT) is thought to be associated with atherosclerotic diseases in carotid ultrasonography (USG) and increased risk of ischemic stroke has been found to be associated with increased carotid IMT. In this study, we investigated the relationship between P-selectin and TAFI levels, which have been shown to be effective for AIS via carotid IMT, and is considered significant for atherosclerosis.

Materials and Methods: Forty patients with AIS and 22 healthy subjects were included in the study. In both groups, serum P-selectin and TAFI levels were studied at the time of presentation, and on day 7, day 14, and at one month; carotid IMT and stenosis rates were measured by Doppler USG. P-selectin and TAFI levels were compared with carotid IMT in both groups.

Results: There was no significant difference between P-selectin levels and carotid IMT between the groups; TAFI levels were significantly higher in the patient group and were correlated with carotid IMT in both groups.

Conclusion: TAFI increase has been suggested to be a marker of early atherosclerosis in asymptomatic atherosclerosis and ischemic stroke. A positive correlation between TAFI levels and carotid IMT and stenosis rates have been reported; however, the positive correlation between increased P-selectin levels in AIS and carotid IMT was not detected in our study.
\end{abstract}

Keywords: Ischemic stroke, P-selectin, thrombin-activatable fibrinolysis inhibitor, carotid intima-media thickness

Öz

Amaç: Ateroskleroz ve serebral iskemik inmede enflamatuvar süreçlerin rol aldığı, periferik kandaki lökositlerin beyin parankimine göç ettiği bildirilmiş̧ir. Migrasyon serebral endotel hücreleri ve lökositlerin yüzeyinde bulunan adezyon molekülleri yardımıyla gerçekleșmektedir. Bu adezyon moleküllerinden P-selektin trombosit ve endotel yüzeyinde bulunmakta ve lökositlerin endotele gevşek olarak tutunmalarını sağlamaktadır. Akut iskemik inmede serum P-selektin seviyesinin arttığ 1 gösterilmiştir. Bir başka akut iskemik inme belirteci olabilecek molekül trombin ile aktive olabilen fibrinolizis inhibitörü (TAFI) bir prokarboksipeptidaz olup tromboemboli ve inme riskini 6 artırdığı gösterilmiştir. Karotis arter Doppler ultrasonografi (USG) incelemelerinde intima media kalınlığının (IMMK) aterosklerotik hastalıklarla ilişkili olduğu düşünülmekte, karotis İMK arttıkça iskemik inme riskinin arttığı gösterilmiştir. Bu çalışmada akut iskemik inme için farklı mekanizmalar üzerinden etkili olduğu gösterilmiş P-selektin ve TAFI düzeylerinin, ateroskleroz açısından anlamlı kabul edilen karotis İMK ile ilişkisi incelendi.

Gereç ve Yöntem: Kırk akut iskemik inme tanılı hasta ve 22 sağlıklı gönüllü çalışmaya alındı. Her iki grupta başvuru anı, 7., 14. gün ve 1. ayda kan serum P-selektin ve TAFI seviyesi çalışıldı, Doppler USG ile karotis IMKK ve stenoz oranı ölçüldü. P-selektin ve TAFI düzeylerinin her iki grupta karotis İMK ile karşılaştırılması yapıldı.

Address for Correspondence/Yazıssma Adresi: Dilek Yılmaz MD, Konya Numune State Hospital, Clinic of Neurology, Konya, Turkey Phone: +90 5063236491 E-mail: dilekyillmaz@gmail.com ORCID: orcid.org/0000-0003-0996-7739

Received/Geliş Tarihi: 08.07.2018 Accepted/Kabul Tarihi: 20.09.2019

${ }^{\circ}$ Copyright 2020 by Turkish Neurological Society

Turkish Journal of Neurology published by Galenos Publishing House. 
Öz

Bulgular: Hasta ve kontrol grubu arasında P-selektin düzeyi ve karotis internal maksiler arter kalınlığı karşılaştırıldığında anlamlı fark saptanmadı ancak hasta grubunda TAFI düzeyleri kontrol grubundan anlamlı olarak yüksek ve her iki grupta TAFI düzeyleri karotis İMK kalınlığı ile korele bulundu.

Sonuç: TAFI artışının asemptomatik aterosklerozun ve iskemik inmede erken aterosklerozun belirteci olabileceği düşünüldü. Akut iskemik inmede gösterilen artmış serum P-selektin düzeyi ile karotis arter IMK arasındaki pozitif korelasyon çalışmamızda saptanmadı ancak serum TAFI düzeyi ile karotis arter İMK ve stenoz oranları arasında pozitif bir ilişki gösterildi.

Anahtar Kelimeler: İskemik inme, P-selektin, trombin ile aktive edilebilen fibrinolizis inhibitörü, karotis intima-media kalınlığ

\section{Introduction}

Atherosclerosis is a pathologic process characterized by intimal thickening and lipid deposits in middle- and large-sized arteries in the entire arterial system $(1,2,3)$. Atherosclerotic plaques tend to develop in the cerebral arterial bifurcations, mainly in the carotid bifurcation, in the cervical segments of vertebral arteries, at the origin of the basilar artery, and within the intracranial circulation, and frequently involve the carotid artery syphon and the origin of the anterior and middle cerebral arteries (4). The rate and level of carotid intima-media thickness (IMT) is related to the risk for cardiovascular disease and stroke $(5,6,7,8)$.

There is increasing evidence for the role of an inflammatory processes in atherosclerosis and ischemic stroke. The migration of peripheral blood leukocytes into the cerebral parenchyme has also been reported in ischemic stroke $(1,9)$. The migration is mediated by adhesion molecules present on the surface of cerebral endothelial cells and leukocytes. P-selectin, which is an adhesion molecule of the selectin family and present on the surface of platelets and endothelial cells, provides loose adhesion of leukocytes to the endothelium. P-selectin levels are elevated in acute ischemic stroke (AIS) (1). Thrombin-activatable fibrinolysis inhibitor (TAFI), another molecule that can be a marker of AIS, is a procarboxypeptidase, which is accepted to be a risk factor for thromboembolism. It has been shown that TAFI increases the stroke risk by 6-fold (2).

The purpose of this study was to evaluate the relationship between P-selectin and TAFI, two markers that act through different mechanisms in AIS, and carotid IMT, which is accepted to be significant in atherosclerosis.

\section{Materials and Methods}

\section{Patients and Control Group}

The study included 40 patients with AIS and 22 control patients with appropriate age and other demographic characteristics. The patients, who had been admitted within 48 hours of symptoms onset, were diagnosed as having AIS. According to the patient's history, neurologic examination, and neuroradiologic imaging scans, they were divided into subgroups as atherothrombotic, cardioembolic, and lacunar infarct based on the Classification of Cerebrovascular Disease III of the National Institute of Neurological Disorders and Stroke. Patients with a history of acute thrombotic disease within the last year, acute inflammatory disease, connective tissue disease, acute or chronic renal/hepatic failure, malignancy, steroid use, and hemorrhagic infarct were excluded from the study. Those who died before completion of the study were also excluded. The patients' characteristics including age, sex, smoking habit, and use of alcohol and drugs were noted.

The patients were questioned regarding the possible risk factors for atherosclerosis. All patients underwent a neurologic examination, and a comprehensive survey including brain computed tomography and/or magnetic resonance imaging scans, electrocardiography, echocardiography, and high-resolution B-mode carotid and vertebral Doppler ultrasonography (DUSI). The clinical data obtained from all patients included age, sex, and presence or absence of hypertension, diabetes mellitus, hyperlipidaemia, cardiac disease, smoking, previous history of stroke, and family history of stroke. The patients' serum total cholesterol, low-density lipoprotein (LDL)-cholesterol, high-density lipoprotein-cholesterol, and triglyceride levels were measured using the standard enzymatic tests.

The patients were divided into atherothrombotic, cardioembolic, and lacunar infarct subgroups according to the trial of org 10.172 in acute stroke treatment classification. On admission, all patients were scored according to the National Institutes of Health Stroke Scale (NIHSS), Rankin, and the Barthel scales. The local ethics committee approved the study protocol.

\section{Evaluation of Carotid Intima-Media Thickness}

Within the first five days of the symptoms, the IMTs of both common carotid arteries were measured, and the presence of stenosis was noted. In the presence of stenosis, the rate of stenosis was determined. Both patients and controls were categorized according to IMT, which included groups of $<1 \mathrm{~mm}$ vs $\geq 1 \mathrm{~mm}$ thickness, respectively. An IMT of $\geq 1 \mathrm{~mm}$ were accepted as pathological $(5,6)$.

\section{Collection of Blood Serum Samples}

Blood samples were collected from the patients on admission within the first 48 hours of stroke, on the $7^{\text {th }}$ and the $14^{\text {th }}$ days, and at the first month. The specimens were left to coagulate for 20 minutes and then centrifuged for 15 minutes in order to separate the sera. Subsequently, the sera were assessed using microenzyme-linked immunosorbent assay (ELISA), using the "human sP-selectin kit" and "TAFI kit". Concurrently, the sera were also tested for biochemical and hematologic parameters.

\section{Statistical Analysis}

The SPSS for Windows Version 15.0 package program was used for the statistical analysis of the obtained data. Numerical variables are expressed as mean \pm standard deviation and categorical variables as numbers and percentages. The t-test was performed 
in independent groups in order to determine the age difference between the patients and controls.

The chi-square test was performed to determine the difference between the patient and control groups in terms of categorical variables. The time-wise change in NIHSS was assessed using the Wilcoxon test. The time-wise changes in levels of serum P-selectin and TAFI were assessed using repeated variance analyses. The Bonferroni test was used for double comparisons. A p value of $<0.05$ was accepted as statistically significant.

\section{Results}

The test group of the study comprised 15 females $(37.5 \%)$ and 25 males $(62.5 \%)$, making a total of 40 patients, diagnosed to have AIS. The age of the patients ranged from 45 to 80 , with a mean age of $64.1 \pm 10.1$. The control group included 13 females $(59.1 \%)$ and nine males $(40.9 \%)$ individuals with a mean age of $60.5 \pm 6.2$. There was no difference between the patient and the control groups in terms of age and risk factors $(p>0.05)$. The demographic features of both groups have been presented in Table 1.

\section{P-selectin Levels}

No significant difference was determined between the patient and the control groups in terms of serum P-selectin levels determined on the first (admission day), $7^{\text {th }}$, and $14^{\text {th }}$ days, and at the first month $(\mathrm{p}>0.05)$. There was no relevant significant difference between any time periods in either group $(p>0.05)$ (Table 2).

There was no significant difference between the patient and the control groups with IMT $<1$ and $\geq 1 \mathrm{~mm}$ in terms of serum P-selectin levels $(p>0.05)$. When the patients were grouped according to infarct location, 23 patients had anterior circulation infarcts, 13 patients had posterior circulation infarcts, and four patients had lacunar infarcts. There was no significant difference between the localization groups or in each group in terms of serum P-selectin levels $(\mathrm{p}>0.05)$.

\section{Thrombin-Activatable Fibrinolysis Inhibitor Levels}

The serum TAFI levels of the patient group determined on the first (admission day), $7^{\text {th }}$, and $14^{\text {th }}$ days, and at the first month

\begin{tabular}{|c|c|c|c|}
\hline & $\begin{array}{l}\text { Patients } \\
(\mathrm{n}=40)\end{array}$ & $\begin{array}{l}\text { Controls } \\
(n=22)\end{array}$ & $\mathrm{p}$ \\
\hline Age $($ mean $\pm S D)$ & $64.1 \pm 10.1$ & $60.5 \pm 6.2$ & 0.068 \\
\hline Gender (M/F) & $\begin{array}{l}25 / 15 \\
(62.5 \% / 37.5 \%)\end{array}$ & $\begin{array}{l}9 / 13 \\
(40.9 \% / 59.1 \%)\end{array}$ & 0.171 \\
\hline Hypertension & $27(69.2 \%)$ & $10(45.5 \%)$ & 0.155 \\
\hline Diabetes mellitus & $13(33.3 \%)$ & $2(9.15 \%)$ & 0.080 \\
\hline Smoking & $18(46.2 \%)$ & $5(22.7 \%)$ & 0.144 \\
\hline Hyperlipidemia & $14(35.9 \%)$ & $14(63.6 \%)$ & 0.057 \\
\hline $\mathrm{IMT} \geq 1 \mathrm{~mm}$ & $16(40 \%)$ & $6(27.3 \%)$ & 0.469 \\
\hline Stenosis $\geq 50 \%$ & $11(27.5 \%)$ & $3(13.6 \%)$ & 0.342 \\
\hline
\end{tabular}

were significantly higher than those of the control group $(\mathrm{p}<0.05)$ (Table 3) (Figure 1).

When the serum TAFI levels of the patient and control groups with IMT $<1 \mathrm{~mm}$ were compared, the levels of the patient group determined on the first (admission day), $7^{\text {th }}$, and $14^{\text {th }}$ days, and at first month, were found to be significantly higher than those of the control group $(p<0.05)$ (Table 4).

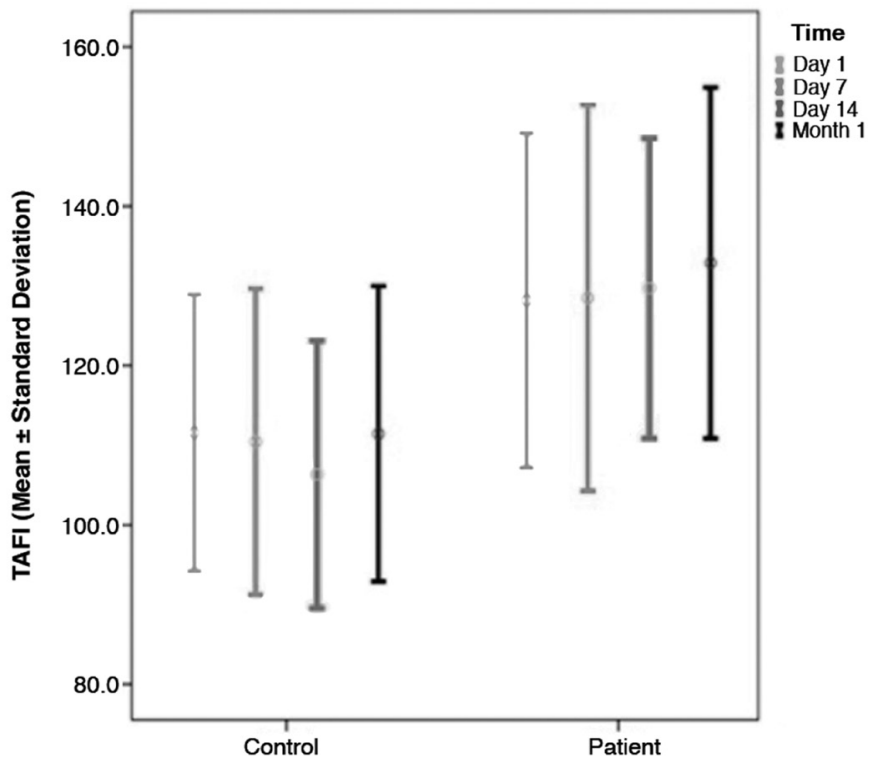

Figure 1. Serum thrombin-activatable fibrinolysis inhibitor levels in patient and control groups all time periods

\begin{tabular}{llll}
$\begin{array}{l}\text { Table 2. Serum } \\
\text { control groups }\end{array}$ & $\begin{array}{l}\text { P-selectin levels in the patient and the } \\
(\mathbf{n}=40)\end{array}$ & $\begin{array}{l}\text { Controls } \\
(\mathbf{n}=22)\end{array}$ & $\begin{array}{l}\mathrm{p} \text { (between } \\
\text { the groups) }\end{array}$ \\
Day 1 & $27.0 \pm 7.8$ & $27.1 \pm 5.1$ & 0.940 \\
Day 7 & $27.2 \pm 8.3$ & $28.4 \pm 5.6$ & 0.553 \\
Day 14 & $25.1 \pm 6.1$ & $28.0 \pm 5.0$ & 0.066 \\
Month 1 & $25.9 \pm 7.0$ & $27.3 \pm 4.8$ & 0.406 \\
$\begin{array}{l}\text { p } \\
\text { (within the group) }\end{array}$ & 0.150 & 0.815 & - \\
\hline
\end{tabular}

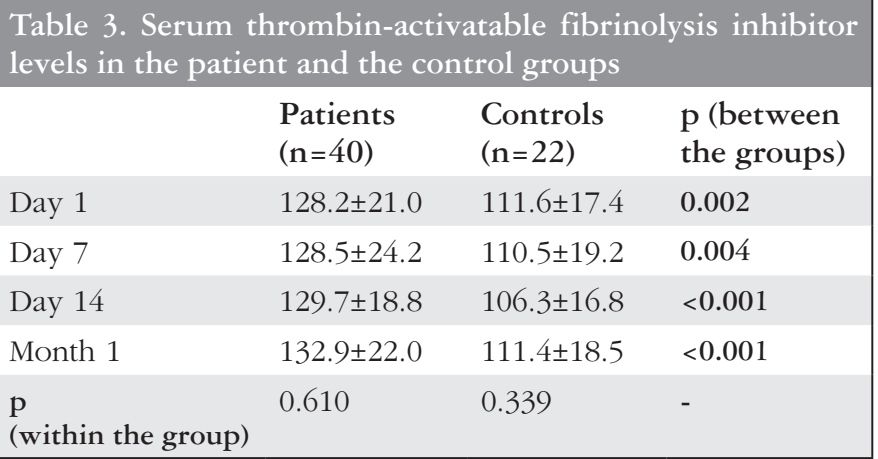


Although it was not statistically significant, the serum TAFI levels in the patient group displayed a time-wise elevation pattern, ranging from the lowest level on the admission day and highest at the first month. However, there was no significant difference in the TAFI levels between the time periods in either group ( $p>0.05)$. When the serum TAFI levels in the patient and the control groups with IMT $\geq 1 \mathrm{~mm}$ were compared, the patient group showed higher serum TAFI levels in all time periods, but significantly higher levels were only observed on the $14^{\text {th }}$ day $(\mathrm{p}=0.035)$ (Table 5).

When the patients were divided into subgroups according to the infarct location, the subgroup of large vessel atherosclerosis demonstrated higher TAFI levels than the lacunar infarct subgroup on the $14^{\text {th }}$ day and at the first month $(\mathrm{p}=0.047$ and $\mathrm{p}=0.033$, respectively). Based on the location, the serum TAFI levels in posterior circulation infarcts tended to be higher than those of anterior circulation infarcts; however, the difference did not reach significance.

\section{Discussion}

Many studies have shown that the inflammatory response in stroke plays an important role in the pathogenesis of cerebral ischemia. It has been reported that acute-phase reactants, adhesion molecules, and cytokines are locally synthesized during the development of brain lesions. However, the prognostic values of inflammatory markers in this pathology have not yet been elucidated (9).

Under normal conditions, P-selectin and E-selectin are not found on the surface of arterial endothelium. However, P-selectin

Table 4. Serum thrombin-activatable fibrinolysis inhibitor levels in the patient and the control groups with intimamedia thickness $<1 \mathrm{~mm}$

\begin{tabular}{|llll|}
\hline & $\begin{array}{l}\text { Patients } \\
(\mathrm{n}=24)\end{array}$ & $\begin{array}{l}\text { Controls } \\
(\mathrm{n}=16)\end{array}$ & $\begin{array}{l}\mathrm{p} \text { (between } \\
\text { the groups) }\end{array}$ \\
Day 1 & $125.0 \pm 21.3$ & $110.0 \pm 16.6$ & 0.023 \\
Day 7 & $128.1 \pm 22.5$ & $107.4 \pm 19.2$ & 0.004 \\
Day 14 & $129.3 \pm 19.7$ & $104.6 \pm 16.9$ & $<0.001$ \\
Month 1 & $136.1 \pm 20.5$ & $112.0 \pm 18.7$ & 0.001 \\
$\begin{array}{l}\text { p } \\
\text { (within the group) }\end{array}$ & 0.066 & 0.264 & - \\
\hline
\end{tabular}

Table 5. Serum thrombin-activatable fibrinolysis inhibitor levels in the patient and the control groups with intimamedia thickness $\geq 1 \mathrm{~mm}$

\begin{tabular}{|llll|}
\hline & $\begin{array}{l}\text { Patients } \\
(\mathbf{n}=16)\end{array}$ & $\begin{array}{l}\text { Controls } \\
(\mathbf{n}=6)\end{array}$ & $\begin{array}{l}\text { p (between } \\
\text { the groups) }\end{array}$ \\
Day 1 & $133.0 \pm 20.1$ & $115.9 \pm 20.3$ & 0.092 \\
Day 7 & $129.0 \pm 27.4$ & $118.7 \pm 18.3$ & 0.409 \\
Day 14 & $130.3 \pm 18.0$ & $111.0 \pm 17.0$ & $\mathbf{0 . 0 3 5}$ \\
Month 1 & $128.1 \pm 24.0$ & $110.0 \pm 19.8$ & 0.117 \\
$\begin{array}{l}\text { p } \\
\text { (within the group) }\end{array}$ & 0.767 & 0.601 & - \\
\hline
\end{tabular}

and other endothelial adhesion molecules are amply released in the presence of cerebral infarct or from atherosclerotic plaques. An increase in P-selectin and E-selectin during stroke and during the inflammatory and healing processes of atherosclerosis induces leukocyte migration (10,11). Kozuka et al. (12) reported that soluble P-selectin level was elevated in the acute phase due to endothelial damage and platelet activation. In AIS, thrombin formation, oxygen radicals, and other endothelial and platelet stimulants elevate the levels of P-selectin of endothelium- and platelet-origin $(12,13)$. As a result of their studies with carotid DUSI, Shimizu et al. (14), reported that the levels of P-selectin were significantly higher in patients with atherosclerosis than in those without atherosclerosis, and also significantly higher in nonstroke patients with atherosclerosis than in non-stroke and nonatherosclerotic controls. They claimed that the level of P-selectin could be a marker of atherosclerosis in asymptomatic patients (14). In our study, there was no significant difference between the atherosclerotic and non-atherosclerotic groups in terms of the serum P-selectin levels, a finding that does not support this claim. We found no difference between the acute phase and subacute phase serum P-selectin levels in the patients either. These two findings, differing from those in other studies, could be due to low sensitivity of the kit used or inadequate titration when assessing the serum P-selectin levels.

The relationship between TAFI and thromboembolic diseases has been widely studied and the possible relationship of plasma TAFI with embolic diseases has been underlined. Due to its critical role between coagulation and the fibrinolytic system, TAFI could play a role in the etiopathogenesis of atherothrombotic diseases (15,16). Montaner et al. (17) determined an increase in TAFI Ag levels within the first 24 hours of stroke. The positive correlation between the elevation of serum TAFI levels and the number of leukocytes led the authors to consider this elevation in TAFI as an acute-phase response. However, they claimed that elevated serum TAFI levels could be a risk factor for ischemic stroke because the elevated levels of C-reactive protein normalized on the $7^{\text {th }}$ - $14^{\text {th }}$ days of AIS, and that the elevated TAFI levels in the acute phase and after the third month were similar (17). Santamaria et al. (2) studied the relationship between plasma functional TAFI levels and the risk for ischemic stroke in a total of 164 subjects including 14 patients with ischemic stroke and 150 controls. They found significantly higher levels of functional TAFI in patients with ischemic stroke than the controls. They determined that in case of a functional TAFI level of $>120 \%$, the risk for ischemic stroke was increased by 6-fold (2). Aso et al. (18) demonstrated that there was a positive correlation only between the plasma TAFI concentrations and LDL-cholesterol. In our study, we found no significant relation in all time periods between the serum TAFI levels and risk factors such as age, sex, hypertension, diabetes mellitus, and smoking. Here, we compared the serum P-selectin and TAFI levels in patients with AIS and the control group. We also assessed the relation of these molecules with internal carotid IMT and etiologic subgroups in the patient group. When the serum TAFI levels in the patient and the control groups with IMT $\geq 1 \mathrm{~mm}$ were compared, the patient group demonstrated higher serum TAFI levels on the first (admission day), 7 th, and $14^{\text {th }}$ days, and at the first month, but significantly higher 
levels only on the $14^{\text {th }}$ day; however, there was no significant difference in P-selectin levels. Etiologically, in cases of large vessel atherosclerosis in the patient group, serum TAFI levels were significantly high on the $14^{\text {th }}$ day and at the first month. This condition can be explained by the continuing endothelial damage in the subacute phase of large vessel atherosclerosis. There are studies in the literature reporting that endothelial damage may be limited by the acute phase of lacunar infarct (12). According to the location, although not statistically significant, the serum TAFI levels in the posterior circulation were found to be higher than that in the anterior circulation.

Antibody measurements with ELISA are affected particularly by Thr325 polymorphism in the TAFI gene, and also measure the other plasma forms of TAFI (free TAFI, plasminogen-bound TAFI, inactive TAFI, TAFI $\alpha$ ), hence, changing the results. Recently, a TAFI active kit, which is not affected by other isoforms and Thr325 polymorphism (19) has been used. We also used this kit in our study.

\section{Conclusion}

Further studies on larger patient groups are required in order to clarify the roles of P-selectin and TAFI in atherothrombotic diseases and to find new therapeutic approaches. Due to its critical role in the balance between serum P-selectin and coagulation and fibrinolysis, a marker of platelet activation, increased TAFI could be a marker of asymptomatic atherosclerosis, and early atherosclerosis in ischemic stroke could be a new risk factor for the development of ischemic stroke, as reported in many studies in the literature. Large randomized studies on better described patient populations and using measurement methods unaffected by other isoforms of plasma TAFI are recommended for future research.

\section{Ethics}

Ethics Committee Approval: All procedures performed in studies involving human participants were in accordance with the ethical standards of the institutional and/or national research committee and with the 1964 Helsinki Declaration and its later amendments or comparable ethical standards. We declare that this study has been approved by the Local Ethics Committee (Gazi University, date: 25/05/2011-179).

Informed Consent: Informed consent form was obtained from all participants.

Peer-review: Externally peer-reviewed.

\section{Authorship Contributions}

Surgical and Medical Practices: D.Y.O., S.A.K., A.O., B.K., Concept: D.Y.O., B.K., Design: D.Y.O., B.K., Data Collection or Processing: D.Y.O., Literature Search: D.Y.O., R.K., Writing: D.Y.O.

Conflict of Interest: No conflict of interest was declared by the authors.

Financial Disclosure: The authors declared that this study received no financial support.

\section{References}

1. Marquardt L, Ruf A, Mansmann U, et al. Course of platelet activation markers after ischemic stroke. Stroke 2002;33:2570-2574.
2. Santamaria A, Oliver A, Borrell M, et al. Risk of ischemic stroke associated with functional thrombin-activatable fibrinolysis inhibitor plasma levels. Stroke 2003;34:2387-2391.

3. Drouet L. Atherothrombosis as a systemic disease. Cerebrovasc Dis 2002;13(Suppl 1):1-6.

4. Van Gils MJ, Bodde MC, Cremers LG, Dippel DW, van der Lugt A. Determinants of calcification growth in atherosclerotic carotid arteries; a serial multi-detector CT angiography study. Atherosclerosis 2013;227:9599.

5. Sinha AK, Eigenbrodt M, Mehta JL. Does carotid intima media thickness indicate coronary atherosclerosis? Curr Opin Cardiol 2002;17:526-530.

6. Kingwell BA. Wall changes induced by blood pressure and antihypertensive drugs in large arteries. In: Touboul PJ, Hennerici M, eds. Intima-Media Thickness, Drugs and Stroke. (1st ed) 2002:19-24.

7. Ebrahim S, Papacosta O, Whincup P, et al. Carotid plaque, intima media thickness, cardiovascular risk factors, and prevalent cardiovascular disease in men and women: the British Regional Heart Study. Stroke 1999;30:841850 .

8. Touboul PJ, Hennerici MG, Meairs S, et al. Mannheim carotid intima-media thickness and plaque consensus (2004-2006-2011). An update on behalf of the advisory board of the $3 \mathrm{rd}$, 4th and 5 th watching the risk symposia, at the 13th, 15th and 20th European Stroke Conferences, Mannheim, Germany, 2004, Brussels, Belgium, 2006, and Hamburg, Germany, 2011. Cerebrovasc Dis 2012;34:290-296.

9. Schmid-Schonbein GW. Analysis of inflammation. Ann Rev Biomed Eng 2006;8:93-131.

10. Lindsberg PJ, Grau AJ. Inflammation and infections as risk factors for ischemic stroke. Stroke 2003;34:2518-2532.

11. Pasterkamp G, Schoneveld AH, van der Wal AC, et al. Inflammation of atherosclerotic cap and shoulder of the plaque is a common and locally observed feature in nonruptured plaques of femoral and coronary arteries. Arterioscler Thromb Vasc Biol 1999;19:54-58.

12. Kozuka K, Kohriyama T, Nomura E, Ikeda J, Kajikawa H, Nakamura S. Endothelial markers and adhesion molecules in acute ischemic stroke - sequential change and differences in stroke subtype. Atherosclerosis 2002;161:161-168.

13. Okada Y, Copeland BR, Mori E, Tung MM, Thomas WS, del ZoppoGJ. $\mathrm{P}$-selectin and intercellular adhesion molecule-1 expression after focal brain ischemia and reperfusion. Stroke 1994;25:202-211.

14. Shimizu M, Kohara S, Yamamoto M, Ando Y, Haida M, Shinohara Y. Significant relationship between platelet activation and intra-media thickness of the carotid artery in patients with ischemic cerebrovascular disease. Thromb Res 2006;117:647-652.

15. Bouma BN, Marx PF, Mosnier LO, Meijers JC. Thrombin-activatable fibrinolysis inhibitor (TAFI, plasma procarboxypeptidase B, procarboxypeptidase R, procarboxypeptidase U). Thomb Res 2001;101:329354.

16. Mosnier LO, von dem Borne PA, Meijers JC, Bouma BN. Plasma TAFI levels influence the clot time in healthy individuals in the presence of an intact intrinsic pathway of coagulation. Thromb Haemost 1998;80:829-835.

17. Montaner J, Ribo M, Monasterio J, Molina CA, Alvarez-Sabin J. Thrombinactivatable fibrinolysis inhibitor levels in the acute phase of ischemic stroke. Stroke 2003;34:1038-1040.

18. Aso Y, Wakabayashi S, Yamamoto R, Matsutomo R, Takebayashi K, Inukai T. Metabolic syndrome accompanied by hypercholesterolemia is strongly associated with proinflammatory state and impairment of fibrinolysis in patients with type 2 diabetes: synergistic effects of plasminogen activator inhibitor-1 and thrombin-activatable fibrinolysis inhibitor. Diabetes Care 2005;28:2211-2216.

19. Guimaraes AH, van Tilburg NH, Vos HL, Bertina RM, Rijken DC. Association between Thrombin Activatable Fibrinolysis Inhibitor genotype and levels in plasma: comparison of different assays. $\mathrm{Br} \mathrm{J}$ Haematol 2004;124:659-665. 